\title{
Discussion on Engineering Education and Curriculum Reform
}

\author{
Daolai Cheng, Yingjie Yin, Zhihao Zhou, Dong Zhiguang, and Xiaoyan Guan, Member, IEDRC
}

\begin{abstract}
For engineering university, its ultimate goal is to cultivate high-leveled, application-oriented graduate. So, engineering education, engineering ability cultivation, curriculum teaching and curriculum teaching reformation is vital. Firstly, the meaning of engineering educations is discussed in the paper. Then, the history, achievements, problems and weakness of China's engineering education are analyzed. Thirdly, opportunities and challenges of China's engineering education are put forward. Finally, some opinions are given that: Engineering education is very consanguineous relation with China's curriculum. A better curriculum system decides the excellent engineering education. These description or argumentations are in favor of the development of China's engineering education and curriculum reform, be beneficial to the construction of applied university, be useful for cultivating excellent applied graduates.
\end{abstract}

Index Terms-Student cultivations, engineering education, curriculum, teaching reformation.

\section{INTROCTION}

There are different kinds of colleges or universities: research (science) model, applied (technology or engineering) model, comprehensive (science and technology) model. The aim of these university is to cultivate its students in an all-round way, namely, morally, intellectually, physically aesthetics. For engineering university, emphases on ability cultivation are the key. So, engineering university's target is train their students to become advanced engineering and technological personnel who are armed with knowledge of modern science and a remarkable ability in application and problem-solving undertaking. Shanghai Institute of Technology (SIT) [1], [2] is an applied engineering university; she endeavors to build a high-leveled, application-oriented, multiple-disciplined university of higher learning with its outstanding features and into "a cradle for engineers".

In order to become a high-level applied institute, engineering education and relative curriculum reformation is pivotal and vital, and it is very consanguineous relation with China's curriculum. A better curriculum system decides the excellent engineering education. In the paper, these topics are discussion, including the meaning, the history;

Manuscript received January 10, 2013; revised March 28, 2013

Daolai Cheng, Zhihao Zhou, Dong Zhiguang, and XiaoYan Guan are with the College of Urban Construction and Safety Engineering, Shanghai Institute of Technology, Shanghai 201418, P.R. China (email: daolaicheng@163.com).

Yingjie Yin is with the Department of Mechanical and Electrical Engineering, Shijiazhuang Institute of Railway Technology, Shijiazhuang 050041, Hebei Province, P.R. China ( email: yyj652005@126.com). achievements; problems and weakness; opportunities; China's curriculum and curriculum reform; and challenges for China's engineering education. These description or argumentations are in favor of the development of China's engineering education and curriculum reform, be beneficial to the construction of applied university.

\section{The MEANING OF ENGINEERING EdUCATIONS}

Engineering educations is the activity of teaching knowledge and principles related to the professional practice of engineering. It includes the initial education for becoming an engineer and any advanced education and specialization that follow. Engineering education is typically accompanied by additional examinations and supervised training as the requirements for a professional engineering license. And it is much related with technology education. However, technology education in primary and secondary schools often serve as the foundation for engineering education at the university level.

As an example, in the United States [3]-[5], engineering education is a part of the stem in public schools. Service-learning in engineering education is gaining popularity within the variety of disciplinary focuses within engineering education including mechanical engineering, construction science, computer science and engineering, electrical engineering, and other forms of related education. In SIT, there also have such engineering majors as mechanical engineering college, civil engineering college, and engineering creation college, and so on.

\section{China’s EngineERING EdUCATION [6]-[8]}

\section{A. The History of China's Engineering Education}

Engineering education is not a fresh topic. In China, her engineering education is not a fresh began with the founding of Beiyang University in 1895. Since the establishment of the Peoples Republic in 1949, Chinese engineering and technology have developed rapidly. In 1952, China adjusted college -department system, and emulating the Soviet model, re-designed the majors to meet the needs of an industrializing nation. In 1953 there were a total 215 majors for all disciplines. This number increased to 328 in 1957, and then on to some 1039 in 1980, 537 of which were engineering majors. Since these majors were so narrowly defined and their curriculums were so specialized, the graduates of this era often felt it was difficult to meet the needs of the jobs. China is today the largest producer of engineering graduates in the world, with over 1000,000 passing out of its colleges and universities. 


\section{B. Achievements Made in China's Engineering Education}

There are different aspects for China's engineering education' achievements such as education scale fast expansion, positive changes in the educational structure, educational reform.

\section{1) China's education scale fast expansion}

With the many years development, fast expansion has formed for China's engineering education. From 2000 to 2010 , the number of enrolled undergraduates and junior college students grew by $12 \%$ annually on average to 6.618 million in 2010.The total number of on-campus students at 22.318 million. The number of engineering students with newly enrolled ones accounts for one third of the total. China's engineering students top the list in the total both in terms of the number and the ratio. The young people receive higher engineering education, which lays foundation for the labor demand in the process of China's industrialization [Table I]. By the year of 2010, the gross admission ratio of higher education had reached $26.5 \%$.

\section{2) Positive changes in the educational structure}

- The renewed focus on vocational education. In 2010, 3.105 million were enrolled into the higher vocational institutes, accounting for $47 \%$ of whole newly enrolled.

- Positive changes also take place in degree education.The degree of professional master based on application and practice has been approved and seen rapid development, among which the engineering masters take up the largest proportion. In 2010, the enrollment number for professional degree was 245,000 , accounting for $41 \%$ and of them, 115,000 were applying for engineering masters.

TABLE I: CHINA's ENGINEERING EDUCATION EXPANSION SCALE

\begin{tabular}{|l|c|c|c|c|}
\hline & $\begin{array}{c}\text { number of } \\
\text { new students } \\
\text { (in millions) }\end{array}$ & $\begin{array}{c}\text { among which, } \\
\text { the number } \\
\text { of } \\
\text { engineering } \\
\text { students }\end{array}$ & $\begin{array}{c}\text { total } \\
\text { on-cam } \\
\text { pus } \\
\text { students }\end{array}$ & $\begin{array}{c}\text { among } \\
\text { which, the } \\
\text { number of } \\
\text { engineering } \\
\text { students }\end{array}$ \\
\hline year of 2000 & 2.206 & 0.832 & 5.561 & 2.148 \\
\hline year of 2010 & 6.618 & 2.412 & 22.318 & 8.031 \\
\hline $\begin{array}{l}\text { average } \\
\text { annual } \\
\text { growth rate }\end{array}$ & $12 \%$ & $11 \%$ & $15 \%$ & $14 \%$ \\
\hline $\begin{array}{l}\text { among which } \\
\text { the average } \\
\text { annual } \\
\text { growth rate } \\
\text { in the first } \\
\text { five years }\end{array}$ & $18 \%$ & $17 \%$ & $23 \%$ & $20 \%$ \\
\hline
\end{tabular}

\section{3) Educational expense is growing dramatically}

4) Educational quality is improving

Some new majors have been launched, including engineering ones, like environmental science and engineering, information, new materials, new energy and energy conservation, aeronautics and astronautics as well as oceanographic engineering, etc. The engineering teaching is added by new contents of social science and human science, like economics, law and ethics, etc.

\section{5) Educational reform is going well}

The new teaching model highlights needs determination and students' value orientation, the comprehensive engineering training and the overall reform on the curriculum system guided by practice.

\section{6) International cooperation is advancing}

The number of on-campus overseas students has exceeded 120,000 , up by over $50 \%$ during the period of eleventh five-year plan.

\section{Problem and Weakness in China's Engineering Education}

Although many achievements have made for China's engineering education, some problems \&weakness exist.

Firstly, contradiction between supply and demand can not be avoided: On one hand, a significant part of universities graduates found it difficult to find a job, the other hand, many enterprises could not find persons they need; the annual growth rate of employment in the second and tertiary industries stands only at $4.5 \%$ the number of graduates every year grows by double digits.

Secondly, schools' development goals and models are getting assimilated: Because administrative management by level is conducted on universities and colleges, higher education institutions were divided higher vocational schools, general schools and 211 schools, 985 schools, academic, teaching-academic and teaching schools. There are first-class universities and non-first-class universities. This hierarchy is closely linked to a schools and school leaders' level, and to financial and other supports for a school as well.

Thirdly, practice in learning lack: The experimental conditions of universities are seriously weakened. Schools have weak link with enterprises, students have very few chances to go to the enterprises for practice.

Fourthly, the curriculum is not orientated towards the engineering features, and lack in the systematic and comprehensive thinking for engineering.

Finally, students are short of capabilities and ethics.

\section{Opportunities and Challenges of China's Engineering Education}

\section{1) New many developments have progressed for China's engineering education}

These developments include: 1) Schools' efforts to develop will depend on reforms on the engineer system and administrative system of running school. 2) Industrial transformation will help to solve the problems about nurturing talents by combining production with academic learning. 3) Teachers will become the main force in the teaching reform. 4) Students' all-round qualities should be improved through efforts in various aspects.

\section{2) Opportunities exists for China's engineering} education

The opportunities brought by the globalization of engineering education, including global research collaboration, joint-programs between universities and international curriculum accreditation.

\section{3) The challenges of Chinese engineering education confront with entering the 21 st century}

The main challenges stem from the changes in the requirements of the graduates' knowledge and abilities imposed by a rapidly changing society and increasing international competition. 


\section{CHINA'S CURRICULUM AND CURRICULUM REFORM}

Engineering education is very consanguineous relation with China's curriculum. A better curriculum system decides the excellent engineering education.

\section{A. The Status of China's Curriculum}

Because of many reason, our knowledge or contents of curriculum is backward, and fall behind the development of socioeconomic environments and the advance in sciences and technologies. Inadequate attention is paid to the importance of the individual's development and the ability of creativity and practice.

At the same time, curriculum is usually overloaded. Their all scores are nearly 200 during four years. This, in turn, poses a negative effect on learning/ teaching: students spend much time on studying curricula but less other activities; even more, there are few graduates cannot obtained bachelor's degree when they graduate, which affect their future development in society.

In order to solve the problem, following curriculum reforms notion or approach are put forward.

\section{B. Curriculum Reforms Approaches}

1) Optimizing and integrating curriculum: such as reduce overdue knowledge or integrate cross-knowledge or relative knowledge. It is very important for teachers in classroom to instruct their students grasp studying methods and skills.

2) Crossing curricular: Because, the cross-curricular approach has the advantage of highlighting a given area from multiple angles, thus allowing an interdisciplinary approach to the topic introduced.

3) Reducing teaching hours.

4) Focus on the relevance of the curriculum to the modern word:

- Integration or emphasis on bilingual curriculum teaching: As countries are increasingly opening up to the rest of the world, the mastering of foreign languages has become an additional or important challenge, first and foremost it is English, then information technology, and communicative and cooperative skills in life. At the same time, international exchange are increasing between China and other countries among teacher and students, some new course system (such as the curricula of 3+2 master of architecture, SIT \&LTU) has formed.

- Increased flexibility curriculum system. Traditionally, the design and implementation of curriculum is too centralized, the development and ability of local-based and school-based curriculum are still weak. Curriculum setting is the key node in cultivating student comprehensive ability in university. The curriculum allows more room for flexibility and creativity by schools and teachers. Teachers are given more freedom in organizing their instructional periods.

- Increased focus on competencies. The current curriculum requires the integration of knowledge, skills and values. Life skills and all other types of skills that may contribute to the development of the individual are crucial in the educational process today. Our college (SIT) and many other universities of China are taken steps by introducing integrated practice and activities education; community service and social practices; laboring and technology, etc. These subjects( active curricula) help students develop their abilities of collecting and dealing with information; problem solving by using comprehensively learnt knowledge; communicating and cooperating; strengthening the sense of social responsibility; and gradually forming the spirit of creativity.

\section{CONCLUSIONS}

Engineering education is very consanguineous relation with China's curriculum. A better curriculum system decides the excellent engineering education. More and more engineering graduates are faced with the rapid economic and technological development in China. Increasing the scale of engineering education and improving educational quality are the major aims of Chinese engineering education today.

From the above research :we understand the meaning of engineering educations, the history of China's engineering education; achievements made in China's engineering education; problems and weakness in China's engineering education; opportunities and challenges of China's engineering education; China's curriculum and curriculum reform. These description or argumentations are in favor of the development of China's engineering education and curriculum reform, be beneficial to the construction of applied university, be useful for cultivating excellent applied graduates and . their career ambitions.

\section{ACKNOWLEDGMENT}

This paper is supported by the Shanghai excellent curriculum "Auto Control and Thermal Instrument".

\section{REFERENCES}

[1] Sit.Edu. [Online]. http://www.sit.edu.cn/s/97/t/227/p/15/c/5751/list.htm

[2] L. Qing, Engineering Education-reform and development, Beijing: Bei Hang University Press, 2010, ch. 2, pp. 9-12.

[3] J. B. Johnson, "Engineering education," presented at the Annual Meeting of the Society for the Promotion of Engineering Education, U.S.A: N.Y., July 17-19, 2010.

[4] C. J. Finelli and A. Matthew, "An Assessment of Engineering Students" Curricular and Co-Curricular Experiences and Their Ethical Development," Journal of the Higher Education Academy Engineering Subject Centre, vol. 6, no. 2, pp. 56-64, Nov. 2011.

[5] E. M. Rodriguez-Falcon, A. Hodzic, and A. Symington, "Learning from each other: Engaging engineering students through their cultural capital," Journal of the Higher Education Academy Engineering Subject Centre, vol. 6, no. 2, pp. 29-38, Jan. 2012.

[6] G.-F. Zhu, "Engineering Education in China," High Engineering Education, vol. 30, no. 4, pp.1-7, Jan. 2007.

[7] Multiculture. [Online]. http://www.intime.uni.edu/multiculture/curriculum/

[8] M.-Y. Pan, New Pedagogy of Higher Education, Beijing: Beijing Normal University Press, 2002, ch. 3 pp. 35-37.

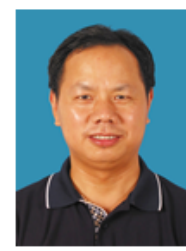

Daolai Cheng was born in 1965 . He is $\mathrm{PhD}$. professor in Shanghai Institute of Technology, China. His research interests include education and teaching of thermal power, energy saving technology, signal process, mechanical fault diagnosis. 